\title{
A HELYI ÖNKORMÁNYZATOK TÖRVÉNYESSÉGI FELÜGYELETÉNEK MUNKAMÓDSZEREI ÉS JÓ GYAKORLATAI
}

Dr. Pál Emese Ph.D.

egyetemi adjunktus, PTE-AJK Körigazgatási Jogi Tanszéke

A sžerzó kutatási területe: belyi önkormányzatok

A szerrōolérhetösége:pal.emese@,ajk.pte.bu

\section{DOI: https://doi.org/10.47272/KIKPhD.2020.1.1}

\section{ÖSSZEFOGLALÓ}

A jogállamiság és benne a közigazgatás törvényessége biztosításának fontos elemei a helyi önkormányzatok, valamint szerveik, múködésük és döntéshozataluk feletti állami kontroll, amelyben kiemelt szerepe van a fövárosi és megyei kormányhivatalok (a továbbiakban: kormányhivatal) által lefolytatható felügyeleti eljárásnak.

Az európai értelemben vett jogállam demokratikus helyi közigazgatása a törvényeknek alárendelt szabad önkormányzás révén valósul meg. ${ }^{1}$ A Magyarország helyi önkormányzatairól szóló 2011. évi CLXXXIX törvény (a továbbiakban: Mötv.) az Alaptörvényben foglaltakon túl rögzíti, hogy a „Kormány a belyi önkormányzatok törvényességi felügyeletéert felelós minisz̧ter irányitásával, a kormánybivatal útján biatositja a helyi önkormányzatok törvényességi felügyeletét." A törvényességi felügyeletet ellátó szerv a Kormány általános hatáskörű területi államigazgatási szervének ${ }^{2}$ a fôvárosi, megyei Kormányhivatal Hatósági Főosztályának a Törvényességi Felügyeleti Osztálya. ${ }^{3}$ Sőt a törvény az értelmező rendelkezések között szintén deklarálja, hogy a kormányhivatalon az Mötv. értelmezésében a helyi önkormányzat törvényességi felügyeletét ellátó fővárosi vagy megyei kormányhivatal értendő. ${ }^{4}$ Jelen tanulmány a kormányhivatali beszámolókban szereplô módszerek és gyakorlatok feltárására vállalkozik.

\section{KULCSSZAVAK}

Helyi önkormányzatok, jogállam, kormányhivatal, törvényességi felügyelet.

\footnotetext{
${ }^{1} \mathrm{~T} / 4864$. sz. törvényjavaslat a helyi önkormányzatokról. http://www.parlament.hu/irom39/04864/04864.pdf (2020.06.02.) 54. o.

2 Magyarország Alaptörvénye 17. cikk (3) bek (a továbbiakban: Alaptörvény).

${ }^{3}$ A szervezeti struktúra, illetve elnevezés tekintetében két kivétel akad a kormányhivatalok között. Az egyik Budapest Fôváros Kormányhivatala, ahol Építésügyi és Örökségvédelmi, Hatósági, Oktatási és Törvényességi Felügyeleti Főosztályon belül található a Törvényességi Felügyeleti Osztály. A másik eltérő megnevezést használó Kormányhivatal a Csongrád Megyei, amelynél a Jogi és Hatósági Főosztály keretei között működő Jogi és Törvényességi Felügyeleti Osztály látja el az önkormányzatok törvényességi kontrolljához, továbbá a Kormányhivatal szervezeti működéséhez kapcsolódó jogi és koordinációs feladatokat.

${ }^{4}$ Mötv. 1.5 2) pont
} 


\section{Bevezetés}

A jogállam demokratikus helyi közigazgatása a törvényeknek alárendelt szabad önkormányzás révén valósul meg. A helyi önkormányzás a helyi közügyekben önszervező és decentralizált hatalomgyakorlást jelent. A helyi önkormányzás során a választópolgárok helyi közössége demokratikus formában és módon kifejezi, valamint saját helyi önkormányzati szervezete révén megvalósítja a helyi közakaratot. ${ }^{5} \mathrm{Az}$ önkormányzati rendszer kialakításakor a demokratikus múködés, az önkormányzati autonómia, illetve a kormányzati túlhatalmat megakadályozó garanciák beépítésén volt a hangsúly - a történelmi hátteret megnézve ez természetszerúnek tetszik - a kialakított struktúra már ekkor magában hordozott több olyan ellentmondást (pl. az elaprózott településszerkezet és a széles feladatrendszer közötti feszültség( $)$, amely később érthető módon múködési zavarokhoz vezetett.

Széleskörű egyetértés volt abban, hogy a reform tehát elkerülhetetlen, amelyet a meglévő értékek megőrzésével és több új elem beillesztésével kell eszközölni, megőrizve a demokratikus jogállam alapelveinek a helyi hatalomgyakorlásban is érvényesülő szabályait.7 A 2012 január elsején hatályba lépett Alaptörvény változást hozott a helyi önkormányzatok feletti törvényességi kontroll tekintetében is. Az alkotmányozó hatalom egy új, a centralizáció irányába mutató alapokra helyezte a Kormány általános hatáskörű területi államigazgatási szerve, a kormányhivatal és az önkormányzatok kapcsolatát, mivel a törvényességi ellenőrzés megerősítése, felügyeletté történő alakítása mellett tette a voksát. Az Országgyúlés számára a helyi önkormányzatokra vonatkozó szabályokat meghatározó sarkalatos törvény elfogadását az alkotmányozó hatalom az Alaptörvény hatálybalépéséig irányozta elő. ${ }^{8}$

Az Alaptörvény a helyi önkormányzatokat továbbra is a közigazgatás integráns részének tekinti ${ }^{9}$, ugyanakkor a helyhatóságok korábban túlságosan szabadnak ítélt mozgásterét szigorúbb keretek közé helyezi. ${ }^{10}$

\footnotetext{
5 Verebélyi Imre: Az önkormányzati rendszer magyarázata. Budapest, Közgazdasági és Jogi Könyvkiadó, 1993. 17. o.

${ }^{6}$ Ld. erről pl. Csefkó Ferenc: A belyi önkormányzati rendsz̧er. Budapest-Pécs, Dialóg-Campus Kiadó, 1997. 98-104. o.

7 T/4864. sz. törvényjavaslat: i.m. 53-54. o.

${ }^{8}$ Alaptörvény 31. cikk (3) bek.

9 55/2009. (V. 6.) AB határozat

${ }^{10}$ Ez a megyei önkormányzatok tekintetében talán túlságosan szigorúra sikerült. A megyék korábban is meglehetősen szerény jogalkotási hatáskörrel rendelkeztek, a fővárosi és megyei kormányhivatalok felállitásával hatásköreik pedig egyre inkább szűkültek. Az állami hatáskifejtés erősödése az önkormányzati igazgatás területén a megyék vonatkozásában vált a legintenzívebbé (közszolgáltatások átszervezése, megyei listák eltörlése, vagyonuk, gazdasági társaságaik államra történő átszállása). A megyei önkormányzat jelenleg területfejlesztési, vidékfejlesztési, területrendezési, valamint koordinációs feladatokat lát el. [Mötv. 21. \(1) bek.]
} 
A fokozottabb állami kontrollmechanizmus előtérbe helyezése a jogirodalomban vegyes fogadtatásra talált. Egyesek szerint az erősödő centrális kontroll nem jelenti a helyi önkormányzatok jogállásának gyengítését ${ }^{11}$, csupán a súlypont helyeződött át: az autonómia hangsúlyozásáról, az önkormányzatok alapvető funkcióinak kiemelésére. Míg mások a helyi önkormányzati autonómia súlyos csökkenését, az önkormányzatiság formálissá tételét látják, ami visszalépést jelent a (helyi) demokrácia korábbi szintjéhez. ${ }^{12}$ A magam részéről úgy vélem, az a féltve őrzés, ahogyan a jogalkotó az Alaptörvény hatályba lépéséig viszonyult az önkormányzatokhoz nem vált a közigazgatás múködésének javára. Hazánkban az „önállóság felfogás” többször csupán egyoldalúan az autonómiához való jogként jelent meg. Az a tényező azonban, hogy ebből fakadóan az önkormányzatoknak kötelezettségeik is lehetnek, nem volt kellőképpen hangsúlyozva. E megközelítésen a jogalkotó a szakirodalom oldaláról érkező vélemények nyomására is kétségtelenül változtatni szándékozott és változtatott. Alaptörvényi szintre emelte az önkormányzat jogalkotási kötelezettsége elmulasztásának következményeire vonatkozó szabályozást és intézményesítette a törvényességi felügyeletet, ugyanis „fel kell(ett) adnia azt az illúziót, amely a helyi önkormányzatnak államon kívüli szerepet tulajdonított."13 Másképpen Magyary Zoltánt idézve: „Az önkormányzat nem szünteti meg a közigazgatás egységét, söt egyöntetüségét sem. Csak az állami kö̈rigazgatásnak sajátos alakja."14

Az Alaptörvény a kormányhivatal vezetőjének felügyeleti jogköréről az általánosabb keretjellegü ${ }^{15}$ szabályozási funkcióhoz képest részletesebben szól. Ez ugyancsak vegyes megítélésű a szakértők között. Magyarázható egyrészrôl csupán azzal, hogy az új eszközök bevezetése alkotmányos alapokat kívánt ${ }^{16}$, másrészről továbbgondolva, ez is az önkormányzatok etatista felfogását erősítő szándék leképeződése. ${ }^{17}$ Egyébiránt a keretjellegú szabályozás elfogadható, s magam is

${ }^{11}$ Vö. Patyi András: Gondolatok a magyar helyi önkormányzati rendszer általános szabályairól. In: Deli Gergely, Szoboszlai-Kiss Katalin (szerk.): Tanulmányok a 70 éves Bihari Mibály tišteletére. Györ, Universitas Nonprofit Kft., 2013. 385. o.

12 Balázs István: Az önkormányzatokra vonatkozó szabályozás átalakulása. MTA Law Working Papers. 2014/3. 2-4. o.

Tilk Péter: A helyi önkormányzatok az Alaptörvényben. Új Magyar Közigazgatás 2011/6-7. 21. o. Jakab András: Miért nem múködik jól a magyar jogrend és hogyan javíthatjuk meg?. MTA Law Working Papers 2018/1. 14. o.

13 Verebélyi Imre: A tanácsi önkormányzat. Budapest, Közgazdasági és Jogi Könyvkiadó, 1987. 175. o.

${ }^{14}$ Magyary Zoltán: Magyar Közigągatás. Budapest, Királyi Magyar Egyetemi Nyomda, 1942. 113. o.

15 Néhány európai ország alkotmánya igen részletező az önkormányzatok tekintetében, példának okáért: Ausztria, Hollandia, Spanyolország. Ld. erről bővebben. Csefkó Ferenc-Sükösd Ferenc: $A z$ önkormányzatok alkotmányi szabályozásáról. In. Ádám Antal, Kiss László (Szerk.): Elvek és intézmények az. alkotmányos jogállamban. Budapest, [Magánkiadás], 1991. 69-82. o.

16 Balázs István: Gondolatok a helyi önkormányzatokról szóló T/4864. sz. törvényjavaslatról. Jogi iránytü 2011/4. 3. o., Szabó Lajos: Az önkormányzatok törvényességi ellenőrzésének fejlesztése. Magyar Körigazgatás 1993/8. 469-473. o.

17 Ugyanerre a következtetésre jut Pálné Kovács Ilona is: Az önkormányzati rendszer és a területi közigazgatás átalakulása 2010-2013. MTA Law Working Papers 
osztom e körben Ivancsics Imre nézeteit arról, hogy a Kormánynak kell meghatározni a felügyelet részletszabályait. Mindenképpen helytálló meghivatkozni Csefkó Ferenc és Sükeösd Ferenc véleményét is, miszerint egy túlságos részletező alkotmányi szabályozás nem kereteket nyújt, hanem mozgásteret nem hagy, így pedig sérti az önkormányzati önállóságot. ${ }^{18}$

Az Mötv. az Alaptörvényben foglaltakon túl rögzíti, hogy a „Kormány a belyi önkormányzatok törvényességi felügyeletéert felelös miniszter irányitásával, a kormánybivatal útján biztositja a helyi önkormányzatok törvényességi felïgyeletét." A törvényességi felügyeletet ellátó szerv a Kormány általános hatáskörű területi államigazgatási szervének ${ }^{19}$ a fơvárosi, megyei Kormányhivatal Hatósági Főosztályának a Törvényességi Felügyeleti Osztálya. ${ }^{20}$ Sőt a törvény az értelmező rendelkezések között szintén deklarálja, hogy a kormányhivatalon az Mötv. értelmezésében a helyi önkormányzat törvényességi felügyeletét ellátó fôvárosi vagy megyei kormányhivatal értendő. ${ }^{21}$ Jelen tanulmány a kormányhivatali beszámolókban szereplő módszerek és gyakorlatok feltárására vállalkozik.

\section{Kapcsolattartás 22}

Kiemelt munkamódszernek tekinthető a polgármesterekkel és a hivatali ügyintézőkkel való rendszeres kapcsolattartás, a területfelelősi jegyzői, valamint személyes konzultációk az önkormányzati vezetőkkel. Az elmúlt évek tapasztalatai alapján megállapítható, hogy ez utóbbi a prevenció hatékony eszköze, illetőleg a javaslat megtételének, információ kérésének a színtere is lett.

https://jog.tk.mta.hu/uploads/files/mtalwp/2014 02 Palne Kovacs Ilona.pdf (2020.06.08.) 6. o.

18 Csefkó Ferenc-Sükösd Ferenc: i.m. 73. o. Az önkormányzatok alkotmányban történő szabályozásának részletességével kapcsolatosan éles ellentét van Bragyova András és Fürcht Pál felfogása között. Előbbi álláspontja szerint, hiba lenne az önkormányzatokról túl sokat és túl részletesen szólni az Alkotmányban, és csupán azoknak az alapvető elveknek a kimondására kellene szorítkoznia, amelyek függetlenek attól, hogy éppen milyen önkormányzati igazgatási rendszer kíván bevezetni a törvényhozó. Míg utóbbi szerint e tétel elfogadása a jogállam tartópillérét szolgáltatná ki a mindenkori kormánynak. Ld. Bragyova András: Egy üj alkotmány koncepciója. Közgazdasági és Jogi Könyvkiadó, 1995. és Fürcht Pál: Az új Alkotmány önkormányzati normáihoz. Magyar Közigaazgatás 1995/1 6. sz. 330. o.

19 Alaptörvény 17. cikk (3) bek.

${ }^{20}$ A szervezeti struktúra, illetve elnevezés tekintetében két kivétel akad a kormányhivatalok között. Az egyik Budapest Főváros Kormányhivatala, ahol Építésügyi és Örökségvédelmi, Hatósági, Oktatási és Törvényességi Felügyeleti Főosztályon belül található a Törvényességi Felügyeleti Osztály. A másik eltérô megnevezést használó Kormányhivatal a Csongrád Megyei, amelynél a Jogi és Hatósági Főosztály keretei között működő Jogi és Törvényességi Felügyeleti Osztály látja el az önkormányzatok törvényességi kontrolljához, továbbá a Kormányhivatal szervezeti múködéséhez kapcsolódó jogi és koordinációs feladatokat.

${ }^{21}$ Mötv. 1.\$2) pont

22 A törvényességi felügyeleti eljárásban történő kapcsolattartást veszem górcső alá, de az önkormányzatokkal való speciális kapcsolattartást ír elő a Mötv. 32.S (2) bekezdés j) pont és a 2011. évi CLXXIX. törvény. a nemzetiségek jogairól ( a továbbiakban: Njtv.) 101. \(1) bekezdés e) pont képviselő képzésére vonatkozó rendelkezése. 
A konfliktuskezelés gyakran alkalmazott módja az egyeztető tárgyalás, amely vagy a helyszínen, vagy igény szerint a kormányhivatalban zajlik. Ennek érdekében a kormányhivatal munkatársai rendszeresen részt vesznek testületi üléseken, ahol szakmai iránymutatással igyekeznek a jogszerú működés kereteiről tájékoztatást adni és biztosítani a testületeken belüli konfliktusok feloldását az önkormányzat alkotmányos múködésének biztosítása érdekében. 2016. június 2 . napjától hatályban lévő kormánymegbízotti írásbeli utasításnak megfelelően, a törvényességi felügyeleti szakügyintézők kötelesek részt venni a járási hivatal székhelye szerinti települési önkormányzatok valamennyi képviselő-testületi ülésén, az illetékes járási hivatalvezetőkkel együtt. Emellett több kormányhivatal az önkormányzati tisztviselők részére folyamatos, soron kívüli és közvetlen konzultációs lehetőséget biztosít. Ez megnyilvánulhat telefonon, elektronikus levelezés formájában és személyes megbeszéléseken keresztül.

Bács-Kiskun megyében a szakmai anyagok, figyelemfelhívások gyakori módja a valamennyi vagy az érintett önkormányzatok, nemzetiségi önkormányzatok részére elektronikusan kiküldött körlevél. A tárgyköröket az aktuális feladatok, ill. a telefonon több hivatalból, önkormányzattól érkezett kérdések határozták meg.

Baranya megyében a Kormányhivatal honlapján múködtetett elektronikus felületen, a Közigazgatási Elektronikus Dokumentumtár (KED) rendszeren keresztül kerülnek kiértesítésre a jegyzők, az önkormányzatok a jogszabályi változásokról, szakmai segítségnyújtásként egy-egy jogszabály-értelmezésről. Itt történik az adatszolgáltatás kérése és a tájékoztatás is. A KED rendszer jól múködő, bejáratott informatikai felület az önkormányzatokkal való kapcsolattartásra, különösen akkor, ha valamennyi önkormányzatot rövid úton kell elérni, illetve tájékoztatni.

A törvényességi felügyeleti munka a legtöbb kormányhivatalban referensi, méghozzá területfelelősi (Baranyában járási területi referensi rendszerben), illetve szakreferensi (Zala megye) vagy ágazati referensi (Györ-Moson-Sopron megye) rendszerben múködik, a fơvárosban pedig minden fóvárosi kerületi önkormányzatnak állandó ügyintézője van a kormányhivatalban.

Ez az osztott funkció biztosítja, hogy egyrészt egy-egy szakreferens a szakmai területén mélyebb ismeretek birtokában nyújthasson gyors és magas színvonalú tájékoztatást konkrét problémák esetén akár munkatársainak is, az egyes témákhoz kapcsolódó hatályos joganyag, $\mathrm{AB}$ határozatok, és a Kúria határozatainak részletesebb feldolgozását, elemzését, vizsgálati szempontrendszerek kidolgozását követően. Másrészt a területi referensi beosztásnak megfelelően az érintett kormánytisztviselő sokkal több és szerteágazóbb információval rendelkezik a hozzá tartozó településekrőll.

Nem elhanyagolható tényező az sem, hogy a törvényességi felügyeletet ellátó szervek (elsősorban a szomszédos megyék) is állandó kapcsolat tartanak fenn egymással. Véleményem szerint e kölcsönös szakmai egyeztetés hasznosnak 
bizonyulhat minden érintett számára valamennyi önkormányzatot érintő vagy egyedi ügyben. Sőt akár alkalmas lehet olyan közös állásfoglalások kibocsátására is, amelyek a jövőben mintegy precedensértékkel bírhatnak a hasonló jogsértések kezelése tekintetében.

A kormányhivatali javaslattétel esetén az írásbeli kapcsolattartás jogszabályban meghatározott informatikai rendszerbe történő feltöltés útján, míg információkérés és a szakmai segítségnyújtás során az írásbeli kapcsolattartás papír alapon, elektronikus úton vagy az informatikai rendszerbe történő feltöltéssel. Ez utóbbi két esetben, de kizárólag ebben, a helyi önkormányzatok törvényességi felügyeletének részletes szabályairól szóló 112/2012. (VI.26.) Korm.rendelet (a továbbiakban: Vhr.) lehetőséget biztosít személyesen, hangkapcsolatot biztosító elektronikus eszközzel, elektronikus levelezés vagy rövid szöveges üzenet formájában történő kommunikációra is. ${ }^{23}$ Amennyiben az információkérésnek az érintett nem tesz eleget, úgy kerül sor a felügyeleti eszközök -elsőként a törvényességi felhívás- alkalmazására. Ugyanakkor, és ez nagyrészt egységes képet mutat a vonatkozó hivatali gyakorlatban, ha a szóbeli megkeresésre nem érkezik reakció, úgy a referensek még felhívás kibocsátása előtt megkísérlik a papír alapú vagy írásbelinek minősülő elektronikus úton történő kapcsolatfelvételt.

A 2014. évtôl a kapcsolattartás fő formája az NJT Törvényességi Felügyelet Írásbeli Kapcsolattartási modulja, amely biztosítja a helyi önkormányzatok törvényességi felügyeletéért felelős miniszter, a kormányhivatal, valamint a helyi önkormányzat közötti, a helyi önkormányzatok törvényességi felügyeletével összefüggő írásbeli kapcsolattartást. ${ }^{24}$

A Nemzeti Jogszabálytár (a továbbiakban: NJT) honlapjára az önkormányzatok 2013. július 1-je óta töltik fel a rendeleteiket, és bár a rendszer gyorsabb és közvetlenebb kapcsolatot biztosít, valamint a jegyzők számára jelentős könnyebbséget jelent a jegyzőkönyvek e felületen történő megküldése, továbbá az írásbeli kommunikációt - így a törvényességi felügyeleti eljárás lefolytatását - is jelentősen meggyorsította (pl. Győr-Moson-Sopron megyében), hiányosságok a 2017. évig előfordulnak.

Több hivatal jelezte, hogy a felület múködtetése a jegyzók, önkormányzati hivatalok részéről problémásnak tekinthető, és emiatt jelentős adminisztrációs teher hárul a törvényességi felügyelet munkatársaira. Ezzel szemben a Fővárosi Kormányhivatal beszámolójából az derül ki, hogy a felület használatát az önkormányzatok elsajátították, mindennapi munkájukba beépítették a jegyzőkönyvek és rendeletek tekintetében, ám a szakmai segítségnyújtás iránti megkereséseiket az NJT felületén és papír alapon, postai úton is felterjesztik. A jegyzőkönyvek felterjesztése tekintetében ugyan egyértelmű javulás mutatható ki több megyében (Baranya, Csongrád, Vas megye) a rendeletek publikálása általában

\footnotetext{
${ }^{23}$ Vhr. 5. S (1)-(5) bek.

24 338/2011. (XII.29.) Korm.rendelet a Nemzeti Jogszabálytárról 8/A. \Az NJT felületén történik különböző körlevelek, tájékoztatók kiküldése és az OSAP adatszolgáltatás is.
} 
késéssel, de több esetben jelentős határidő-túllépéssel történik. A jegyzők jellemzően nem tudják tartani a jogszabályban előirt rövid határidőt. ${ }^{25}$

Gyakori hibák:

- a törvényességi felügyeleti intézkedésre nyújtott válaszok NJT. felületére történő feltöltésének elmaradása; ${ }^{26}$

- ugyanazon ügyhöz tartozó „,események” külön bejegyzésként történő rögzítése a rendszerbe és az ügyek összekapcsolása nem történt meg;

- a kormányhivatal által kezdeményezett ügyet az önkormányzat nem nyitotta meg határidőn belül;

- $\quad$ a feltöltött testületi dokumentumok tekintetében az ügy megnevezésében nem szerepel más ügytől elkülöníthető megjelölés;

- az önkormányzat nem aláírt, bélyegzővel ellátott, szkennelt dokumentumot csatolt fel vagy a dokumentum ugyan aláírt, de a hitelessége kérdéses;

- a módosító rendeletek esetén a módosítás önálló közzétételének hiánya.

E hiányosságoknak, illetve problémáknak a kiküszöbölését a hivatalok igyekeznek elősegíteni. Bács-Kiskun megyében például a törvényességi felhívásokban technikai tájékoztatást vezettek be a modul használatáról, a felületen történő válaszadásról, ill. a várt intézkedés megtételének módjáról. Ez több önkormányzat esetében elősegítette a megfelelő használatot. Jász-Nagykun-Szolnok megyében 2014-ben megyei szakmai nap került megszervezésre a rendszer bevezetésével és használatával kapcsolatban.

A jegyzőkönyv-küldésen, valamint a kormányhivatal részéről alkalmazott törvényességi felügyeleti eszközök továbbításán kívül a kapcsolattartás egyéb formái még nem teljes mértékben tevődtek át az elektronikus felületre. Az NJT rendszeren keresztüli kapcsolattartás hatékonyságának növelését a hivatalok a rendszer folyamatban levő fejlesztésétől várják. Ennek érdekében több alkalommal is eljuttatták javaslataikat az üzemeltetôhöz. 2017-ben több hivatal is a modul negatívumaként említette meg, hogy az nem alkalmas adatok gyüjtésére, statisztika készítésére, továbbá a kötelező önkormányzati feladatok teljesítéséről, vagy annak elmulasztásáról szóló adatok összesítésére. Éppen ezért szorgalmazzák a beérkezett iratokat, jegyzőkönyveket rendszerező, az adatgyüjtést elősegítő funkciók életre hívását.

25 Baranya, Bács-Kiskun, Békés Csongrád megyében a 2017. évi OSAP statisztika alapján megállapítható volt, hogy az alkotott rendeletek és az Njt. rendszerben feltöltött rendeletek száma lényeges eltérést mutat.

${ }^{26}$ Bár dolgozatomban nem vizsgálom a nemzetiségi önkormányzatokat, annyit mégis megjegyeznék, hogy a legtöbb hiányosság az ő részükről tapasztalható, különösen igaz ez Baranya megyében, ahol a 2014. évi választásokon a 13 nemzetiségből 9 önkormányzatot. 


\section{Információkérés és javaslattétel}

A Mötv.-ben nevesített információkérési jog megegyezik az ellenőrzési jogviszony tartalmával, amely - mint ahogy e dolgozatban már kifejtésre került - nem más, mint információk szerzése az ellenőrzött szerv tevékenységéről: „,a kormányhivatal a helyi önkormányzat feladat-és hatáskörébe tartozóan az érintettől információt, adatot kérhet, konzultációt kezdeményezhet, amelyeknek az érintett a megadott határidőn belül köteles eleget tenni." 27 Ezt a Vhr. 4. (1) bekezdése annyiban egészíti ki, miszerint az információkérés magába foglalja az iratbetekintési jogot is. Ez azért kardinális kérdés, mert egy ügy megítélésekor a törvényességi referensnek nem csupán a jegyzőkönyvre, vagy - a jelenlegi szabályozás szerint - annak részeként az előterjesztésre, hanem a döntéshozatal megelőző egyéb iratokra is szüksége lehet. ${ }^{28} \mathrm{Az}$ információkeresésre irányuló megkeresés önkormányzat általi negligásának komoly következmény van, a törvény erre az esetre felügyeleti bírságot helyez kilátásba.

A javaslat jogintézménye új rendelkezés a törvényben, amely nem „klasszikus felügyeleti eszköz”, mivel itt nem konkrét jogszabálysértésre hívja fel a kormányhivatal az érintett figyelmét, hanem a múködés körében tapasztalt olyan gyakorlatra, amely jogsértéshez vezethet. ${ }^{29} \mathrm{~A}$ javaslatot a helyi önkormányzat képviselő-testülete, illetve a társulási tanács a soron következő ülésen, ha a megkeresés más határidőt nem tartalmaz, köteles megtárgyalni és arról döntést hozni. Nem köteles azt elfogadni, de az elutasítás indokait 8 napon belül közölnie 12 kell a hivatallal.

Érdekességként megemlíthető Bács-Kiskun megyéből a jegyzőkönyv alakiságához kapcsolódó helytelen gyakorlat megszüntetésére (névbélyegző használata), a testületi határozat végrehajthatatlan, pongyola megfogalmazása miatt a témakör újratárgyalására és egyértelmű döntés meghozatalára tett törvényességi javaslat.

A törvényességi felhívásokat több esetben javaslat, illetve információkérés elózi meg, amelynek hatására - általánosságban elmondható hogy az önkormányzat saját hatáskörében megszünteti a jogszabálysértést. Ebből következően több hivatal gyakorlatában is csökkenő tendenciát mutat a felhívások száma.

\footnotetext{
${ }^{27}$ Mötv. 133. \(1) bek.

28 A kormányhivatali gyakorlat korábban is ezt a rendszert követte, vagyis az iratbetekintést is az információkérés részének tekintették.

29 Nagy Marianna - Hoffmann István (Szerk.): A Magyarország belyi önkormányzatairól szóló törvény magyarázata. Budapest, HVG-ORAC Kiadó, 2016. 545.o.
} 


\section{Szakmai segítségnyújtás}

A szakmai segítségnyújtás eszköze (amelyet 1994-től az Ötv. is nevesített) a német jogdogmatikában megjelenő és a Mötv. koncepciójában is fellelhető együttmúködő felügyelet érvényesülését szolgálja. E modellben a törvényesség megtartását a represszív és a megelőző felügyelet eszközök együttes alkalmazása hivatott biztosítani. ${ }^{30} \mathrm{~A}$ kormányhivatal szakmai segítséget nyújt az érintett részére az általa alkalmazandó jogszabályok tartalmával összefüggésben az érintett jogszerű működése céljából. A Mötv., hatályba lépésekor a szakmai segítségnyújtást még törvényességi felügyeleti eszközként definiálta. 2015. január elsejével e szakaszt hatályon kívül helyezve a jogalkotó megerősítette a törvényességi felügyelet segitő, támogató jellegét, s a szakmai segítségnyújtásra „törvényességi felügyeleti eljárás megindítása nélkül is szükség lehet." "31 Ettől némiképp eltér Arva Zsuðsanna, aki a törvényességi felügyelet „legenyhébb eszközének” nevezi a szakmai segítségnyújtást. ${ }^{32}$

A törvényességi ellenőrzés szünetelésének idején - a várttal ellentétben nem nőtt az önkormányzatok részéről a szakmai segítségnyújtás iránti igény. A hivatalok ekkor gyakran választották azt a megoldást, hogy jogszabálysértés észlelés esetén, de a segítségnyújtás iránti kérelem hiányában, jeleztek a jegyzőnek, hogy az az önkormányzat nevében kérje a segítségnyújtást. (Nyilván ez olyan törvénysértés esetén, amelyhez a jegyző is „hozzájárul” nem volt eredményesen járható út). ${ }^{33}$

A szakmai segítségnyújtás természetesen a törvényességi felügyeleti jogkörön belüli jogszabályok értelmezésére terjed ki, nem általánosságban az egész jogrendszerre. A Mötv. testületként múködő szerveket is feljogosít a segítségnyújtás kérésére, de azt minden esetben meg kell elôznie egy testületi döntésnek. Ezt azért fontos hangsúlyozni, mert a képviselők egyéni segítségnyújtásra nem jogosultak, ugyanakkor a hivatalok sokszor ún. jogi állásfoglalást adnak ki a képviselők számára. E gyakorlat aggályos, hiszen a jogi állásfoglalás tartalmát tekintve szakmai segítségnyújtásként fogható fel, mivel az önkormányzati képviselők által alkalmazott jogszabályok tartalmával összefüggésben kerül kiadásra. Márpedig az önkormányzati képviselő kvázi jogalkalmazóként való elismerése a segítségnyújtásra vonatkozó szabályok nyelvtani és logikai értelmezésének is ellentmond. ${ }^{34} \mathrm{~A}$ helyzetet némiképp

\footnotetext{
${ }^{30}$ Uo. 540.o.

${ }^{31}$ Uo. 546.0

${ }^{32}$ Vö. Árva Zsuzsanna: A helyi önkormányzatok feletti törvényességi felügyelet tapasztalatai. In: Árva Zsuzsanna, Szikora Veronika (Szerk.): Jogtudomány a jogfejlödés szolgálatában: Szemelvények a modern jogi kutatások köréböl. Debreceni Egyetem Állam- és Jogtudományi Kar, Debrecen, 2017. 19. o.

33 Vö. Bércesi Ferenc: A törvényességi ellenörzés hiányának hatásai. In: Fábián Adrián (Szerk.): A jegyző helye és szerepe a magyar közigazgatásban. Pécs, A ”Jövő Közigazgatásáért”" Alapítvány, 2010. 11. o.

${ }^{34}$ Vö. Nagy - Hoffmann (Szerk.): i.m. 546.o.
} 
javíthatná, ha Vhr. a szakmai segítségnyújtásról, annak kötelező tartalmi elemeiről, határidejérôl részletesen szólna.

A hivatalokban a szakmai segítségnyújtás preventív módszere tipikusan a szakmai értekezletek tartása, valamint a szakmai anyagok, kiadványok készítése, a kormányhivatal honlapján történő közzététele. A hivatalok által szervezett rendezvények témája a 2013. évben a rezsicsökkentéssel kapcsolatos teendők, 2014. évben a helyhatósági választások, az azt követő feladatellátás és az összeférhetetlenségi és méltatlansági esetek.

A 2012-2013-as évhez képest jelentősen nőtt (Baranya megyében pl. 80\%-kal) a szakmai állásfoglalások iránti igény a rendelet-tervezetek, különösen az SzMSz szabályozásának előzetes kontrollja érdekében, valamint az adósságot keletkeztető ügyletek szakmai véleményezésére. Az egyedi szakmai segítségnyújtások tipikusan a Mötv., az Njtv., az Áht. és a nemzeti vagyontörvény egyes rendelkezéseinek értelmezéséhez, alkalmazásához kapcsolódnak. Jellemzően a legnagyobb igény a szóbeli, illetve az azonnali szakmai konzultációra van.

Szeretném felhívni a figyelmet egy olyan megoldásra, amellyel a BácsKiskun Megyei Kormányhivatal gyakorlatában találkoztam. Ennek lényege, hogy a hivatal 2017-ben elindította az online Önkormányzati Helpdesk felületét a szakmai tájékoztatás érdekében, amelyen naprakész, egységes, nyilvános formában teszi közzé a kormányhivatal részéről az önkormányzatoknak kiadott tájékoztatásokat (függetlenül attól, hogy az a kormányhivatal mely szervezeti egységétól származik), valamint a jegyzők egyes kérdéseire adott, közérdeklődésre is számot tartó általánosított válaszokat.

A felügyeleti munka jelentős része még mindig preventív jellegü, ez tekinthető a leghatásosabb eszköznek. A beszámolókból levonható következtetésem, hogy a törvényességi felügyeleti munka során alapvető szerepe van az együttmúködésnek. Az együttmúködésben részt vevő szervek, szervezeti egységek, valamint az együttmúködés módja a tárgykör és az időtényező függvénye. ${ }^{35}$ A szakmai egyeztetések a legtöbb esetben eredményesek, a felvetett problémák közös átbeszélése segít az álláspontok közelítésében, megoldásában, továbbá alkalmat biztosít nemcsak a tények, hanem a tervek, lehetőségek kölcsönös megismerésére.

\section{V. Összegzés}

A helyi önkormányzatok állami felügyeletének elsődleges célja - hívja fel a figyelmet Ivancsics Imre és Fábián Adrián - a törvényes önkormányzati múködés biztosítása. Az állami szerveknek elő kell segíteniük az önkormányzatok feladatainak az ellátását, miközben arra törekszenek, hogy érvényre juttassák a közigazgatás törvényességének alkotmányos alapelvét is. E megközelítésben pedig

35 A Baranya Megyei Kormányhivatal 2017. évi beszámolója, Bács-Kiskun Megyei Kormányhivatal 2017. évi beszámolója 
a Tamás András által kifejtett bizalmi viszony, amelynek alapvetően kellene jellemezni a központi és önkormányzati szervek közötti kapcsolatot, még inkább felértékelődik. A jogalkotó az Alaptörvény megalkotáskor a törvényességi ellenőrzés-felügyelet dilemmájával kapcsolatosan úgy foglalt tehát állást, hogy a törvénysértés haladéktalan orvoslásához füződő érdek megelőzi az önkormányzati autonómia védelméhez fưződő érdeket.

A kormányhivatali beszámolókból kitűnik, hogy a törvényességi referenseknek egyre több időt és energiát kell fordítaniuk ezeknek a polgármester-képviselő-testület, polgármester-alpolgármester, polgármesterképviselő testület-jegyző között fennálló - személyes konfliktusoknak a rendezésére, amelyek nem is minden esetben oldhatók fel. Az érintettek olyan intézkedéseket várnak a kormányhivataltól, hogy „váltsa le” a polgármestert, oszlassa fel a testületet, holott a jelzett problémák, a vélt vagy valós sérelmek ilyen súlyú lépéseket egyáltalán nem indokolnak.

A felügyeleti tevékenység elemzése alapján megállapítható, hogy az önkormányzatok, a képviselő-testületek és szerveik múködésének jogszerűsége javuló tendenciát tükröz. A korábbi évek felügyeleti tevékenysége, intézkedései pozitív hatást gyakoroltak az önkormányzatok múködésére. Az olyan felügyeleti eszközök bevezetésével, mint az aktuspótlás és a felügyeleti bírság Magyarország azon európai államokhoz csatlakozik, amelyek szigorúbban ellenőrzik önkormányzataikat.

A törvényességi felügyelet eszközei megfontolt megválasztásának, a felhívások megalapozottságának, illetve a területi referensek által szóban, illetve telefon útján nyújtott szakmai segítségnek köszönhetően a felhívásra tett intézkedések jogszerűek és hatékonyak voltak.

Mindazonáltal tartok attól, hogy a helyi önkormányzati közigazgatás egyre kevésbé tényező az állami, társadalmi megitélésben. Szamel Lajos szavai talán ma is helytállónak tekinthetők: „Az önkormányzatok a polgári demokráciának egyik, pusz̨án a formájával is batékeny biztositéka. A jogi szabályozás és a gyakorlat azonban rendszerint felïgyeletnek nevezi ąt a funkciót, amely valójában már döntóen irányitás, s nemcsak a zavaró jelenségek észlelése és azok kikürszöbölése végett kifejtett beavatkozás a "felügyelt" szerv életébe. Márpedig - egyéb tényezök együtthatásával - könnyen vezethet az önkormányzatok tartalom nélküli üres formákká alakitásához: Ekeként pedig könnyen a köaponti kormányzat „demokratikus függelékévé" torzithatók, elég, ha a két világháború közötti „önkormányzati rendszer" emlékét felidézzü̈. ${ }^{36}$

${ }^{36} \mathrm{Vö.} \mathrm{Szamel} \mathrm{Lajos:} \mathrm{Az} \mathrm{államigazgatás} \mathrm{vezetésének} \mathrm{jogi} \mathrm{alapproblémái.} \mathrm{Budapest,} \mathrm{KJK} \mathrm{Kerszöv.,} \mathrm{1963.} \mathrm{183.o.}$ 